\title{
Introduction: a research agenda for military geography
}

\section{Rachel Woodward}

Looking out of my office window at the university where I work, all I can see are military geographies. To my left in the adjacent building, I can see where nearly 40 years ago a geographer modelled the likely impacts of a nuclear weapons strike on the UK. Directly ahead is the museum established at least in part through a 19th-century philanthropic donation from wealth generated by armaments manufacture. The donor's statue is nearby, flanked by bronze panels bearing images of cannons. To my right I can see the interpretation plaque above the entrance to an old tunnel that served as an air-raid shelter in the Second World War, and beyond this I can just about make out one of the war memorials in a city park. Military geographies are everywhere.

A substantial proportion of my academic life has been spent engaging with the ideas that flow after looking at views like this. I am endlessly curious about the imprints made by military activities or priorities, in one way or another, on geographical spaces and in a variety of shapes and forms. But looking at geographical space and noting what's there is only the start. The more essential task lies with trying to understand the causes and consequences of what we see. In the early 2000s, in an effort to do this, I wrote a book called Military Geographies (Woodward 2004) as a means of explaining how military activities and military phenomena could be thought of as being expressed across and constituted by geographical space. The book emphasised how geographical space had to be thought about in terms that accounted for the imprints, visible or otherwise, of military power and control.

I was writing the conclusion to that book when the bombing started. I sat on my sofa with my laptop on successive April evenings in 2003, watching television news coverage from Iraq of the opening salvoes in the ground war unleashed by a US-led coalition of military forces tasked with the removal of the head of the Iraqi state. The violence reverberated out from shattered bodies, smashed concrete and broken lives, and I and millions of other felt it while sitting watching thousands of kilometres away. It felt like the violence was new, and in a way the wars in Iraq and Afghanistan were, of course. In the years which followed, and in response, we saw in disciplinary terms considerable growth in the levels of geographical engagement with questions about military violence and its effects. This response has explored the spatialities inherent to new ways of facilitating and sustaining war and its effects materially, 
culturally, politically, socially and economically. Yet in the geographical imprints of these contemporary 21 st-century forms of military violence and all the things that make it possible, there were still echoes of older patterns, practices, flows of power and continuities in activity which the view from my office window brings to mind.

In part, this book is an attempt to take stock, and to see what the study of the geographical constitution and expression of military phenomena and activities looks like at this point in the 21st century. In this introductory chapter, I provide a brief overview of how military geographies might be defined, and then introduce the 13 chapters in the book. Each suggests a different way of thinking about military geography, and each has a different idea as to the forms that future research agendas could take.

\section{What is military geography?}

A long-standing definition of military geography sees it as the application of the tools and techniques of the discipline of geography to the solution of military problems (Palka and Galgano 200o). There is a history and a logic to this definition, as Andrew Lohman and Christopher Fuhriman explain in Chapter 2. They make clear the importance of geography to military leaders. For all the sophistication of technologies of contemporary warfare, their remotely operated outcomes, and as James Der Derian (2009) notes their seemingly bloodless and virtuous effects, issues such as location, spatial relationality, terrain, people and movement through geographical space are still fundamental to the exercise of lethal force. Understanding those geographies is essential to the conduct of war.

But the study of military geography has also been shaped by wider intellectual contexts, both within the academic discipline of geography and across the wider social sciences and geohumanities. It has been influenced by the emergence of more critical approaches to geography from the early 1970s, informed by Marxist and feminist theories and their focus on social justice and power. It has been influenced too by post-structuralist theories of knowledge, which from the 1980 os have shaped the ways that geographers have moved beyond the objectivity claims of positivist modes of explanation, and which in turn have changed how the study of military phenomena has proceeded in the discipline. The cultural turn in geography in the 1990s, which emphasised the significance of interpretation to understanding the nature of social relationships across space, was followed by increased interest in the experiential and embodied dynamics of human experiences across space, and these have both impacted on how the geographies of military phenomena are studied. Military geography is also influenced by new materialist philosophies and by assemblage thinking, through which we can account for the relationships between animate and inanimate, material and affective components of complex relationships. Some scholars (myself included) use the idea of military geographies (plural) to suggest a plurality of issues, approaches and outcomes, evident when we grapple with the geographical constitution and expression of military phenomena. 
Other scholars consider these issues as central to their academic work, but never use the term 'military geography' or 'military geographies' at all.

Across developments in military geography and geographies, five ideas appear (at least to me) to dominate in our discussions of the spatial constitution and expression of military events and phenomena, and these thread through the chapters of this book. The first is that the study of military geographies is more than the study of war. This opens up opportunities to include consideration of all the things that make military activities possible, and all the things that follow from armed violence, through myriad interventions, connections, relationships and processes within and across space. This is significant for the study of military geography, because it invites attention to issues, features and practices that may at first sight seem far removed from military endeavour. But it is also significant for the field because it raises the question as to whether or not acts of armed violence should have analytic priority. Opinions differ. Associated with this is the prioritising (or otherwise) of peace, as war's binary opposite.

The second idea is that militarism and militarisation are more than just descriptive terms and have analytic weight and utility in understanding military geographies. The concepts of militarism and militarisation figure through this book, with subtle differences in use nuancing chapters' explanations for the spatialities of military phenomena. These reflect broader arguments at play in cross-disciplinary debates about the differences between the analytic categories of 'military' and 'security', for example, or the analytic limits of a thought-system developed around the unstable binaries of 'military' and 'civilian'. Furthermore, and as a number of authors in this volume imply or demonstrate, the broader critical military studies project with its central focus on the analysis of the effects of military power, rests on a processual conceptualisation of militarism and militarisation with spatiality at its core.

Third, the diverse epistemologies, methodologies and tools for data generation and analysis that are used in studies of military geographies are invaluable in driving forward new areas for investigation. The methodological pluralism evident in the wider discipline of geography continues to shape developments in the subdiscipline. Across military geographical research we see qualitative and quantitative work, the use of statistical techniques and interpretative enquiry, personal engagement and engagement with the life-worlds of other people, methods that prioritise practice as a means of enquiry and methods that prioritise detached observation. We see research which responds to talk, text, interaction, networks, enumeration and images. We see analytic responses in prose, in art forms and in activism. Researchers may be personally very distant from what they study, or they may be (or may have been) military operatives themselves. The different chapters in this book show a healthy range of methodological approaches.

Fourth, our individual positionalities are an asset to our interrogation of military geographical phenomena. Central to contemporary human geography practice is acceptance of the validity of positionality, of one's own and that of others. This idea 
is important for this book. Positionality matters because of the insights enabled by different positions in time, space and context, and the possibilities for understanding that are generated by the sharing of multiple and often very different viewpoints. Our world can look very different, depending on where we stand in it, and this idea features clearly in this book's chapters. Engaging with military geographies requires us to grant legitimacy to ideas, approaches and understandings of the world that may be very different to our own.

The final idea is that military geographies need to be considered at a range of scales. This seems almost too simplistic an idea to state so explicitly here, given this book's title. But what is clear in this volume's chapters is that military geographies invite study at scales from the global and international, through the national and regional, to specific urban areas or rural localities, through to the distinctively local and individual. It should also be clear that the study of military activities and phenomena asks us to consider connections at different scales, and the differences that scale makes to the effects (and understanding the effects) of military things. The richness of enquiry into the geographies of military activities and phenomena is in no small part a reflection of the range of scales at which enquiry is conducted.

\section{Chapters and research agendas for military geography}

This collection opens with a comprehensive overview of the history and evolution of teaching and research in military geography by Andrew Lohman and Christopher Fuhriman in Chapter 2. In their explanation of how traditional military geography emerged, and why it continues in the form that it does, they look in depth at studies emerging from the early 19th century in North America and Europe by those working as geographers in active military contexts in service to the state. A key point to understanding the evolution of military geography is recognition of the importance of geography to military leaders, and the close connection between developments in the discipline of geography and the engagement of military forces in armed conflict. Military geography is forged in theatres of conflict, and its role emerges in response to those contexts. The connections between research and teaching, they point out, are absolute because of the applied nature of the sub-discipline, and the more descriptive and less theoretically-orientated mode of writing in traditional military geography reflects the needs of students within military institutions studying geography as part of their military training. Lohman and Fuhriman see a future research agenda for military geography in a diverse range of topics connected by arguments for military geography as an applied practice; technological advances in military capabilities do not negate the basic facts of geography, which will always shape their application in armed conflict.

Chapter 3 draws our attention to the question of armed conflict and geography as an outcome of global militarism. James Tyner and Gordon Cromley's focus is on the genocide that unfolded in Yemen from 2015 as a direct result of efforts to unseat the government by an international coalition led by Saudi Arabia. They 
make explicit the connections between the profound effects of this in terms of the suffering of the Yemeni people, and the causes of this in a form of global militarism that has capitalised financially on armed conflict. Using a historical-geographical materialist framework, they argue that we should understand genocide in the context of global militarism. They are adamant that we see the connections between violence, destruction and deliberate mass death, and the profits made through arms sales by arms corporations which while doing so deny their complicity in the fomentation of genocide. Genocide, in other words, has a political economy, and the study of this is a necessary part of the military geography project. They prompt us to consider a research agenda for military geography which recognises the importance of war and its political economy, and which recognises the significance of the financialisation of war under the neoliberal economic frameworks of dominant contemporary regimes.

In Chapter 4, Becky Alexis-Martin asks us to consider nuclear warfare. Often denoted as an unconventional form of armed conflict because of the extremes of destruction of human life that it threatens, she maps out how nuclear warfare is geographically distinct. The chapter sets out the ways in which the legitimation and regulation of nuclear weapons is undertaken in the context of contemporary international geopolitical orders. It asks about the spaces of threat and spatialities of both regular (state-sanctioned) and irregular nuclear war. Alexis-Martin then asks us to consider the role of geographers in the application of geotechnologies, including (but not only) mapping, in providing representations of nuclear war and its effects. She considers also the geographies of nuclear warfare as they pertain to its materialities and landscapes, including the tourist engagements that it invites, and concludes by questioning possible zones of future nuclear conflict. A research agenda for the study of nuclear warfare's geographies, for Alexis-Martin, sits with analysis of its spatialities and geopolitics, and with accounts of the geographies of its effects.

In Chapter 5, Alison Williams suggests we look upwards to consider what an aerial perspective might bring to the study of military geography research. The significance of the aerial dimension to military activities emerges when we consider airspaces as volumetric and three dimensional. The concept of power projection allows us to see how state-craft and space work together. This chapter looks at the spatialities and uses of the aerial, taking as an example the ways in which UK air space is demarcated and used by military forces. She then goes on to consider how people and technologies work through air spaces, exploring the questions raised by the use of drones and wider technologies by human bodies. The research agenda set by this chapter rests on taking forward a different perspective on geographical space - in this case, the aerial dimension - and how this can be used to explore military geographical phenomena. The chapter reminds us too of the importance of remembering the human dimensions of this, including the responses of those tasked with the deployment of military power from above.

Chapter 6 examines the material and discursive spatialities of military deployments and militarisation, through which Brittany Meché explores the case of the West 
African Sahel. She makes the point that the construction of arid spaces as problematic in military operations and thinking reflects the co-constitution of ideas of militarisation and the spaces where such ideas are deployed. The chapter explores how discourses of the global war on terror resonate with environmental anxieties about arid and semi-arid spaces, with desert-scapes becoming sites of security governance. Looking at military interventions by (primarily) the US armed forces, she examines how arid spaces are imagined in particular ways, and how they forge particular kinds of militarised knowledge. The deserts of the West African Sahel have come to be constructed militarily as inherently dangerous spaces, and the Sahel as a form of security laboratory. A research agenda suggested here is for the exploration of the construction of ideas about different types of spaces as appropriate (or otherwise) for military interventions. Further, Meché makes the point about the need for geography to understand how environmental change as a result of climate change has come to be constructed as a military and security issue.

In Chapter 7, Craig Jones discusses the intersections between war, law and military geography. Arguing that law, military violence and war are conditioned by one another from the outset, he shows how modern military operations are increasingly dispersed in time and space and have come to require ever more complex modes and layers of legal regulation. Jones reminds us that this is yet another example of the co-constitution of militarisation and social life. Looking closely at the law-war relationship allows us to distinguish between the military geographies of law, and juridical military geographies, and looking at this relationship also helps us understand the contemporary redrawing of the lines between 'war' and 'peace'. Jones takes us through the range of legal inflections that exist around military phenomena, such as rules of engagement, basing, recruitment, landscapes and victim compensation. Advocating a military geography that is more centrally focused on war, a research agenda is suggested which prioritises asking of any military geographical phenomenon which laws apply, and where.

Chapter 8 considers the economic dimension and Emily Gilbert guides us through an examination of the connections between money, finance, war and military activities. She looks at a new and lethal set of relationships which have emerged between military forces and money, and her focus is primarily on the armed forces of the USA. She explains the ways in which military forces work closely with the financial sector and argues for finance-security linkages to be understood as an ever-evolving and deepening assemblage. Examining the ever-closer engagements between military forces and counter-threat finance, Gilbert directs our attention to big data analytics and artificial intelligence, and the connections between militaries and technology companies that use sophisticated data analysis as part of their arsenal in counter-terrorism and other operations. The research agenda suggested by Gilbert is for the closer exploration of military capitalism and the links and assemblages that consolidate finance-security connections and the spatialities inherent in that.

In Chapter 9, Chih Yuan Woon examines the materialities, actors and practices evident when we turn our attention to everyday military geographies. He asks that we 
consider in particular how embodied and performed activities might constitute a significant element of military geographical enquiry. Drawing on a case study of the Mindanao region in the South Philippines, Woon brings military personnel into the frame, looking at their activities working with local communities and assessing the evidence of the transformative potential of such acts. He provides us with explanations of such transformations in security provided by children in the locality who were able to articulate a set of understandings about what military interventions might mean. Woon argues for a research agenda which considers the non-human materialities that mediate militarism in ways that make it visible, and which also considers the human interactions with materialities at the scale of the everyday.

Chapter 10, by Edmore Chitukutuku and Godfrey Maringira, looks at military landscapes, and argues for an approach to military geographies that takes account of the intangible and the spiritual. Drawing on their work in African military contexts, they explore the understandings of military personnel engaging with the landscapes of deployment in ways that paid heed to the idea of spiritual beings as actors within military spaces. They use the example of the liberation war in Zimbabwe which preceded its independence from colonial rule in 1980, and look at accounts given by liberation fighters, who drew on a Zimbabwean cosmology to account for the meanings held by animals and geographical features in places of deployment. This was significant both to fighters themselves as individuals making sense of their involvement in war, but also as a point of comparison between the world-views of the ZANLA liberation fighters and those of the Rhodesian army (which was based on a British model). Chitukutuku and Maringira see engagements with spirituality as indicative of the ways that different military forces engage with the spaces of war. The research agenda that they suggest attends to the spiritual and unseen capacities of military landscapes, and to the cosmological beliefs that underpin soldiers' geographical imaginaries of the spaces of deployment.

In Chapter 11, Matthew Kearns asks us to consider military recruitment, and how space and place help constitute the gendered cultures through which recruitment is developed. He writes from the perspective of a feminist international relations scholar with an analysis influenced by geographical ideas, and he uses this to unpack the gendered spatialities evident in contemporary UK armed forces recruitment campaigns. Kearns looks at British Royal Navy recruitment and draws connections between the ideas of military masculinity and representations of adventure contained therein. He shows how particular military masculinities are privileged within recruitment representations and suggests that the ways that particular landscapes are depicted open up possibilities for certain types of places to be viewed as spaces to be acted upon. For Kearns, the research agenda suggested for military geographies takes gender seriously as an operation of power, and he urges us to make gender central to our knowledge claims about military phenomena.

Chapter 12 looks at military theatre and how it might help us understand military power and people's engagements with it. Alice Cree considers theatre as a methodological and conceptual tool for examining the embodied and affective textures 
of militarism, arguing that theatre can be effective to analysis by centring questions of military power. She uses as a case study the play Boots at the Door, which developed from a community theatre project in Plymouth in south-west England. Her interest is in the critical potential of an aesthetic politics and the value of theatre for transformative encounters with military power. She argues in particular for a focus on so-called militarised subjects, those who become militarised by proximity, and for a focus on the inherent liveliness of these subjects and their actions. For Cree, the research agenda for military geographies revolves around our taking forward insights about the affective capacities of military phenomena and their co-opting and normalising effects, the ways in which they can work to minimise the possibility of critique, and the potential of lively militarised subjects in resisting this.

In Chapter 13, the ways in which environmental politics and ecology are mobilised in militarised landscapes is considered by David Havlick. He uses as his examples the former nuclear weapons plant at Rocky Flats, Colorado, USA, the borderlands of the former Iron Curtain in central Europe, and the demilitarised zone between North and South Korea, arguing for a focus on material changes that inform our broader understanding of militarisation, conservation and shifting socio-ecological relations. Havlick discusses the conceptual and practical challenges faced by ecological projects in post-military sites and asks us to consider the paradoxes of erasure. He argues against the loss of meaning at these sites, because such losses entail the loss of the lessons that we can learn from these places. He asks us to consider a research agenda which can assess how new forms of militarised nature emerge in these hybrid spaces, where for all that the military is physically absent it still has to be kept in mind.

Chapter 14 examines the idea of post-military geographies, and in it Matthew Rech and Richard Yarwood discuss how military geographies are shaped by the contraction and reshaping of armed forces. Drawing on the idea of post-military society, they look at the impacts of military contraction with reference to the city of Plymouth in the UK. Their conceptualisation of the post-military is of something that is layered and complex, in which civil society has to be understood as transitioning with and alongside the military, and the military has to be understood as in transition alongside civilian life. The idea of 'post', they argue, indicates both significant change and continued influence. They look at how the post-military is structured, imagined and performed at a range of scales, and they use as their case study the celebrations around Armed Forces Day in the city. The research agenda suggested by Rech and Yarwood prioritises the idea of the civilian and military worlds as co-constituted; they comprise a complex web of entanglements rather than the binary of civil and military that has come to shape our thinking.

\section{A research agenda for military geography?}

Collectively, the 13 chapters in this book are indicative of military geography and military geographies as a lively, plural field of enquiry, engaged with by scholars at 
a range of career stages and from different academic traditions and locations. The intention in producing this book is to communicate something of this diversity and energy both to geographers curious about military phenomena and scholars of military phenomena curious about geography. Notwithstanding likely absences in the coverage of topics and the voices that are heard, the range of perspectives and approaches contained in this volume point both to specific suggested research agendas and also to something more collective. This is around the more diffuse idea of the validity of a sustained intellectual agenda around the study of military activities and phenomena in terms of their geographical constitution and expression. Whether such intellectual endeavour is labelled as 'military geography' or not is beside the point. What seems to me to be crucial is the concern underpinning all the contributions within this book with the moral necessity of scrutinising military phenomena and activities in geographical terms. This is the case whether military power is manifestly evident through direct acts of armed violence, whether it is almost invisible in the prosaic spaces of everyday life where military force seems remote, or whether it occurs in spaces in between.

\section{References}

Der Derian, J. (2009), Virtuous War: Mapping the Military-Industrial-Media-Entertainment Network, second edition, New York: Routledge.

Palka, E.J. and Galgano, F.A. (200o), The Scope of Military Geography, New York: McGraw-Hill.

Woodward, R. (2004), Military Geographies, Oxford: Blackwell. 